\title{
Identification of Victims Response to Bullying Cases: A Study of Javanese Students
}

\author{
Chr. Argo Widiharto \\ Bimbingan dan Konseling Department, Universitas PGRI Semarang \\ Doctoral Student, Faculty of Psychology, Airlangga University \\ argowidiharto@upgris.ac.id \\ Dewi Retno Suminar \\ Faculty of Psychology, Airlangga University \\ dewi.suminar@psikologi.unair.ac.id \\ Wiwin Hendriani \\ Faculty of Psychology, Airlangga University \\ wiwin.hendriani@psikologi.unair.ac.id
}

\begin{abstract}
Bullying is an incident that frequently involves a perpetrator, bystander, and victim. However, victims' responses to stop bullying, does not always achieve the expected outcome. This is partly because the responses vary significantly, and victims does not explicitly show their intention. The purpose of this research is to identify the types of bullying victims' responses and identify which among them should be implemented. The sample are Javanese $4^{\text {th }}$ to $6^{\text {th }}$-grade elementary school students who have witnessed bullying. The total sample of 290 students were taken from the elementary schools in Semarang, Yogya, Wonosobo, Pemalang, and Tegal. The dominant victim response is helplessness and there is no difference between cities and classes.
\end{abstract}

Keywords: Identification of responses, victims of bullying, victim responses, Javanese student

Received 30 September 2019/Accepted I5 May 2020 @JEHCP All rights reserved

\section{Introduction}

Bullying problems have long been a concern in theeducation field, both in terms of its effect on perpetrators and victims (Sittichai \& Smith, 20I5). Bullying is defined as an unpleasant behavior committed by a person or group of people to a weaker party - be it a person or a group-who has no ability to retaliate to physically nor psychological harassment (Olweus, 1996; Wolke, Woods, Stanford, \& Schulz, 200I; Smith, Cowie, Olafsson, \& Liefooghe, 2002; Cheng, Chen, Ho, \& Cheng, 20II). For it to be considered bullying, the so-called unpleasant behavior must be repetitive and harm the victim. Similarly, Rigby (2002) stated that bullying is a behavior that involves the desire or act of hurting others repetitively, which may utilize 
power imbalance and unjust use of force, and result in perpetrators gaining a sense of enjoyment by making victims feel oppressed. Tattum (Smith, Pepler, \& Rigby, 2004) also stated that bullying is a desire to hurt (a person or group of people) using an imbalance of power, of which the aggressive behavior is done repetitively and unfairly.

Bullying brings a detrimental impact on its victims, which include the emergence of suicidal thoughts (Hong, Kral, \& Sterzing, 20I5; Alaviet al., 20I5), social avoidance, loneliness, and being disliked by friends (Georgiou \& Stavrinides, 2008; Shin, 2010). Additionally, victims could also lose their self-control, show reluctance of going to school, experience stress and anxiety (Albdour, Lewin, Kavanaugh, Hong, \& Wilson, 2016), as well as remain as a bullying victimin the future (Olweus, 1996; Busch et al., 2015).

Carmey \& Merrell (200I) stated that victims of bullying experience psychological problems, such as reduced psychosocial adjustments, causing them to remain victims of bullying in the future (Solberg \& Olweus, 2003; Busch et al., 2015). They also show social disintegration, negative self-evaluation, and experience of depression on an ongoing basis. Sanders, Cheryl, \& Phye (2004) affirm that victims of bullying avoid public places at school, such as playgrounds, to avoid being bullied. Victims of bullying often have low self-esteem and experience high levels of stress and depression (Nash, 2012).

Olweus (1993) asserts that there are two types of victims, namely passive victims and provocative victims. Passive victims are characterized by anxious personalities combined with physical weakness. A provocative victim is characterized by a combination of both anxious and aggressive behavioral patterns. Provocative victims provoke antagonism among friends and enjoy aggressive situations.

In facing bullying, victims would determine their response towards the experience, influencing the effectiveness of the victim's attempt to stop the bullying (Kochenderfer-ladd, 2004). Children who respond emotionally to bullying, both passively or aggressively, are likely to experience prolonged bullying. Conversely, the use of problem-solving strategies (e.g., assertiveness, avoidance) in responding to intimidation is associated with lower escalation of bullying episodes. Likewise, Kochenderfer-ladd (2004) found that children who 
respond with anger, shame, and revenge tend to experience more bullying. Conversely, children who focus on conflict resolution in response to bullying tend to experience less bullying. Frightened children are motivated to seek advice to solve bullying problems (Craig, Pepler, \& Blais, 2007).

Kochenderfer-ladd (2004) stated that younger children prefer being nonchalant while older children are more likely to choose retaliation. Situational factors were also found to be related to bullying responses. A study of children conducted by Martin and Gillies (Craig et al., 2007) found that the longer the bullying lasted, the more difficult it was for students to use redemption strategies such as rejection and avoidance.

Salmivalli, Karhunen, \& Lagerspetz (1996) asserted that there are three types of responses from victims of bullying, namely counteraggression, helplessness and nonchalance. Counteraggression occurs when the victim responds by fighting back the bullies. On the other hand, helplessness occurs when victims does nothing - be it defend or seek helpto deal with the bullying they face. A nonchalant response is when the victim does not consider the bullying they experience as a matter that must be responded to seriously, usually choosing to remain calm instead. Additionally, Salmivalli, Karhunen, \& Lagerspetz (1996), Berdondini (Cowie \& Berdondini, 2016) and Sokol, Bussey, \& Rapee (2016) stated that the victim's response to bullying is the strategies used to confront or stop bullying behavior. Victims of bullying can provide different types of responses during different bullying episodes.

Victims' responses to bullying are also influenced by the responses of teachers and peers to bullying behavior that occurs at school (Berkowitz, 20I4). If the victim perceives a positive response from his or her teachers and friends, victim would develop the courage to report bullying. Conversely, if the teachers and friends have a negative perception of bullying, the victim is likely to remain quiet in the experience of bullying. The school climate and environment also affect victims of bullying (Martin, 2015). Victims often give a fabricated response when being bullied following what the victims perceive the perpetrator, as well as the victim's friends and teachers, think is appropriate. For instance, responding with counter aggression so that the perpetrator perceives the victim dares to fight back. Conversely, the 
victim may choose to cry in order to attract attention, which leads the perpetrator to stop bullying (Sokol et al., 2016).

Bystanders' perceptions may differ from the actual response from victims of bullying. However, it is essential to understand a bystander's perception of the victim'sresponse toassist victims in responding to bullying behavior precisely and effectively. Victims often provide specific responses that fulfill the expectations of the perpetrators and bystanders in order to avoid being bullied (Sokol, Bussey, \& Rapee, 2016). Problems arise when the victim's perception of response does not match the expectation of the perpetrators and bystanders, indicating an ineffective response. Bystanders, as a third party in bullying incidents, have the option to either provide support and defend victims of bullying or participate in the bullying act (Trach, Hymel, Waterhouse, \& Neale, 20I0). Previous studies have not explored the correlation between bullying response and ethnic background, particularly in terms of victims from a Javanese ethnic background - known for their value to obey older people, avoid conflict, and maintain harmony (Endraswara, 2012). The purpose of this research is to identify the response of Javanese ethnic victims and the perceived response that should be given to the perpetrators of bullying.

\section{Bullying and the Javanese Culture}

Seal \& Young (2003) mentioned that ethnicity plays a role in the act of bullying, although no further in-depth studies have been done on the matter. Bullying research in various countries which identified the use of different terms to describe bullying and different forms of bullying justifies the opinion of Seal \& Young. A nation's characteristics and social condition will, in fact, influence bullying behavior. Individuals from an Individualistic European culture would differ from those with collective Asian culture in terms of their efforts to address bullying. Indonesia, particularly Java, is an Asian country that has among the highest social characteristics and is known for its subtle/indirect culture and strong social ties.

Among one of the well-known Javanese sayings is 'wong Jawa nggone semu,' implying that Javanese people do not covertly express themselves. The way Javanese communicate is full of cues, otherwise known as 'sasmita' (Endraswara, 2012). Furthermore, Endraswara (2015) stated that Javanese people enjoy being subtle or indirect, meaning that the Javanese do not 
express thoughts or behave openly and tend to use symbolic gestures and words in their stead. Javanese people often use metaphors, symbolism, and other means of disguised/overt forms of verbal expressions in the hope of not offending the person being spoken to. This implies that the Javanese have a strong empathy in interacting with others.

This trait of the Javanese who does not like being frankusually becomes apparent during efforts to educate or convey one's ideas to others (Endraswara, 2012). Ideas are conveyed using cultural symbols. Traditional Javanese people often express their attitudes and actions in vague or disguised forms. Moral teachings concerning Javanese attitudes are always kept secret. Submission of disguised attitudes and behavior is a form of subtlety, indicating that Javanese people do not like vulgarism. Even if Javanese have to act harshly or useanger, they do so subtly.

The refined Javanese teachings, 'ngalah' (to relent), maintaining harmony, and 'setya tuhu' (relentment) are perceived to prevent children from doing unpleasant actions to others. Research by Juwita (Kompas.com, 2008) stated that bullying statistics in Yogyakarta is higher than Jakarta and Surabaya even though Yogyakarta is known for its people's refined behavior. Furthermore, Juwita found that the school which had the lowest bullying statistics in Yogyakarta is located in the suburbs. The results of this study were supported by the statement of the Head of School Psychologists in Bantul (Ketua Forum Guru Pembimbing Psikolog Cabang Bantul), that Yogyakarta ranks highest in cases of physical and psychological violence at school compared to Jakarta and Surabaya (Hana, 20I3).

\section{Method}

\section{Respondents}

A total of $2963^{\text {rd }}, 4^{\text {th }}$, and $5^{\text {th }}$-grade public or private elementary school students participated in this study. Among them, 124 students came from Yogyakarta, 36 students from Semarang, 27 students from Tegal, 36 students from Pemalang, and 72 students from Wonosobo. Purposive sampling was used to select both the students andschools. Selected students were perpetrators of bullying who are of Javanese ethnicity (with both parents being Javanese) and used Javanese as their mother tongue. Snowball throwing techniques were used in interviews 
with teachers and students to identify the perpetrators of bullying. Before obtaining the data, the researchers submitted permission to the School Principal with a permission letter from the Dean of the Faculty of Education at the University of PGRI Semarang. Respondents were also asked about their willingness to be respondents of this study and were informed that data would only be used for academic purposes. The questionnaire was only administered to students who agreed to be a respondent. The process of school sampling also considered the representation of the low and highlands areas, commonly heavily influenced by Javanese culture. This isdisplayed through the use of Javanese as a daily language in interacting with peers.

\section{Questionnaire}

The research was done using survey methods. An open and closed questionnaire based on Salmivali's idea of victims' response to bullying (i.e., counteraggression, helplessness, nonchalance) was used as an instrument for data collection. There were 4 (four) items designed to uncover counteraggression, namely fighting back or retaliation, seeking help, laughing, and mocking the perpetrators. Helplessness was unraveled through items of crying, saying nothing, reporting to a teacher or parent, threatening to report to a teacher or parent, leaving (school) before class ends, being absent from school, and holding back tears. Meanwhile, the items designed to reveal nonchalance were, among others, staying calm and not caring.

Additionally, there were also open-ended questions that provided an alternative for subjects whose answers are not listed in the closed-ended questionnaire. Before students start answering the closed-ended questionnaire, a teacher explained the way to mark the answers. Each respondent was allowed to choose more than one type of available response in the questionnaire and provide other additional responses if their answer was not available on the list. Thus, the types of responses are higher than the number of respondents who filled out the questionnaire.

\section{Design and Data Analysis}

This research used a survey research design. This design was chosen because it is in accordance with the purpose of the study in identifying the response of bullying victims with 
respondents from several cities in Central Java. The survey allows the current researcher to gather a high amount of data in a relatively short time. Data from the survey results were analyzed using descriptive statistics to obtain an overview of the responses of bullying victims from respondents. This descriptive analysis technique describes the collected data and compares the types of bullying victim responses in each class and hometown.

\section{Results}

The questionnaire acquired 720 answers and 19 types of responses from respondents. The most common responses given by victims of bullying, according to bystanders, are reporting to teachers or parents, fighting back or retaliation, seeking help, crying, or doing nothing. Answers categorized by cities showed that reporting to teachers or parents remains to be the most common response in three cities, namely Semarang, Yogyakarta, and Wonosobo. Meanwhile, fighting back or retaliation is the most common response in Pemalang, and seeking help is the most common response in Tegal. Thus, it can be concluded that, according to bystanders, the three primary responses ofvictims are reporting to teachers or parents, fighting back, and seeking help.This conclusion is based on the fact that these three responses are the most common responses in each of the cities sampled. A complete summary of the data can be seen in Table I.

Table I

Types of Response

\begin{tabular}{lcccccc}
\hline \multicolumn{1}{c}{ Response } & Semarang & Yogya & Wonosob & Pemalang & Tegal & Total \\
& & & $\circ$ & & & \\
\hline Report to teacher/parent & 26 & 63 & 34 & 7 & 10 & $\mathbf{1 4 0}$ \\
Retaliate & 10 & 36 & 29 & 14 & 7 & $\mathbf{9 6}$ \\
Seek help & 12 & 40 & 14 & 6 & 11 & $\mathbf{8 3}$ \\
Cry & 20 & 28 & 13 & 8 & 7 & $\mathbf{7 6}$ \\
Stay quiet & 7 & 31 & 29 & 2 & 6 & $\mathbf{7 5}$ \\
Remain calm & 1 & 17 & 22 & 0 & 10 & $\mathbf{5 0}$ \\
Threaten to report & 3 & 27 & 3 & 0 & 10 & $\mathbf{4 3}$ \\
Hold back tears & 9 & 24 & 2 & 1 & 7 & $\mathbf{4 3}$ \\
Do not care & 0 & 18 & 15 & 3 & 4 & $\mathbf{4 0}$ \\
Mock perpetrator & 0 & 9 & 16 & 0 & 0 & $\mathbf{2 5}$ \\
\hline
\end{tabular}




\begin{tabular}{lcccccc}
\hline Patient & 6 & 4 & 3 & 0 & 4 & $\mathbf{1 7}$ \\
Absent from school & 4 & 4 & 0 & 0 & 0 & $\mathbf{8}$ \\
Laugh it out & 1 & 5 & 2 & 0 & 0 & $\mathbf{8}$ \\
Run & 3 & 3 & 0 & 0 & 1 & $\mathbf{7}$ \\
Report to police & 3 & 0 & 0 & 0 & 0 & $\mathbf{3}$ \\
Leave before school & 0 & 1 & 0 & 1 & 0 & $\mathbf{2}$ \\
hour ends & & & & & & \\
Tell a friend & 1 & 0 & 1 & 0 & 0 & $\mathbf{2}$ \\
Stressed & 1 & 0 & 0 & 0 & 0 & 1 \\
Self-protect & 1 & 0 & 0 & 0 & 0 & $\mathbf{1}$ \\
\hline Total Responses & 108 & 310 & 183 & 42 & 77 & 720 \\
\hline
\end{tabular}

Victims' responses were then grouped into three categories based onSalmivalli et al. (1996), namely, counteraggression, helplessness, and nonchalance. Counteraggression includes fighting back or retaliating, seeking help, laughing it out, mocking the perpetrator, and confiding in peers. Responses related to helplessness includes reporting to teachers or parents, crying, staying quiet, threatening to report the bully, staying home from school (being absent), running away, reporting to police, coming home from school early, stress, and self-protection.The nonchalance category only includes three types of responses: fidgeting, not caring, and staying patient. Thus, it can be concluded that there are three primary responses to victims of bullying, namely reporting to the teacher or parent, fighting back, and seeking help because these are the three highest responses in each city in the research sample.

The next step was to compare responses of subjects from the five different cities. In general, bystanders perceive helplessness as the most common response from victims of bullying (55.42\%), followed by counteraggression (29.72\%), and nonchalance (14.86\%). The complete summary of the data can be seen in Table I. Students from all five cities show similar responses, with helplessness as the highest response, excluding students from Tegal who preferred to use counteraggression. However, the latter only had a mere $2.38 \%$ margin with their second-highest response (i.e., helplessness). 
Table 2

Types of Victims' Response to Bullying

\begin{tabular}{lcccccccccccc}
\hline \multirow{2}{*}{ Response } & \multicolumn{3}{c}{$\mathrm{A}$} & \multicolumn{3}{c}{$\mathrm{B}$} & \multicolumn{1}{c}{$\mathrm{C}$} & \multicolumn{1}{c}{$\mathrm{D}$} & \multicolumn{2}{c}{$\mathrm{E}$} & \multirow{2}{*}{ Tot } & $\%$ \\
\cline { 2 - 11 } & & $\%$ & & $\%$ & & $\%$ & & $\%$ & & $\%$ & & \\
\hline Counteraggres & 2 & 22.22 & 90 & 29.0 & 62 & 33.8 & 20 & 47.6 & 18 & 23.3 & 214 & 29.7 \\
sion & 4 & & & 3 & & 8 & & 2 & 8 & & 2 \\
Helplessness & 7 & 71.30 & 181 & 58.3 & 81 & 44.2 & 19 & 45.2 & 41 & 53.2 & 399 & 55.4 \\
& 7 & & & 9 & & 6 & & 4 & 5 & & 2 \\
Nonchalance & 7 & 6.48 & 39 & 12.5 & 40 & 21.8 & 3 & 7.14 & 18 & 23.3 & 107 & 14.8 \\
& & & & 8 & & 6 & & & & 8 & & 6 \\
\hline
\end{tabular}

Note: A: Semarang ; B: Yogyakarta ; C: Wonosobo; D: Tegal; E: Pemalang

Data regarding victims' response to bullying shows no significant differences between grades.

Helplessness related responses rank the highest in all three grades (grade $4=50.33 \%$, grade $5=59.30 \%$, grade $6=54,26 \%)$.

Table 3

Victim's Response to Bullying Based on Grade

\begin{tabular}{lcccccccc}
\hline \multirow{2}{*}{ Response } & \multicolumn{2}{c}{ Grade IV } & \multicolumn{2}{c}{ Grade V } & \multicolumn{2}{c}{ Grade VI } & Total & $\%$ \\
\cline { 2 - 6 } & & $\%$ & \multicolumn{3}{c}{$\%$} & $\%$ & & \\
\hline Counteraggression & 52 & 33.99 & 87 & 30.53 & 75 & 26.60 & 214 & 29.72 \\
Helplessness & 77 & 50.33 & 169 & 59.30 & 153 & 54.26 & 399 & 55.42 \\
Nonchalance & 24 & 15.69 & 29 & 10.18 & 54 & 19.15 & 107 & 14.86 \\
\hline
\end{tabular}

The question about what victims should do when bullied was answered by 264 out of 295 subjects. The answers to the questionabove varied but could be categorized into eight response groups. In the category with the most response ( $n=97 ; 36.74 \%)$, subjects expected victims of bullying to report perpetrators to teachers, parents, or the police. The next most expected response from bystanders is for the victim to fight back or retaliate (21.21\%), followed by expecting the victim to stay quiet in the face of bullying. Other answers include seeking help (7.58\%), remaining patient (7.20\%), forgiving the perpetrator (4.55\%), crying (3.4I\%), and running away $(0.76 \%)$. 


\section{Discussion}

The primary response given by victims of bullying is to report bullying behavior to teachers, parents, or the police. In the Javanese culture, teachers and parents are respected figures who should be obeyed. Javanese culture also teaches children to respect older people. Santoso (2012)identified several values that remain fundamental to the Javanese culture, such as loyalty to people from higher hierarchy, obedience to superiors (manut), and the desire to avoid conflict (Kamarea, 2018). Values such as decency/politeness to parents or older people, as well as other noble principles, continue to be taught by Javanese parents and teachers to their children or students (Rachim \& Nashori, 2007; Idrus, 20I2). Such Javanese teachings explain why victims of bullying mainly choose to react to bullying by reporting to parents or teachers. This is seen as a wayto avoid direct conflict with the perpetrator while expecting teachers and parents to help settle the problem without fuss, as it is believed that bullies would likely obey older figures.

Javanese teachings also explain victims' choice to seek help from other people, such as friends or relatives. Among Javanese people, the habit of helping each other is commonly referred to as 'gotong royong' (mutual cooperation) and is considered a code of conduct for Javanese people. Other codes of conduct such as 'setya tuhu', 'narimo ing pandum', and 'ngajeni' are ideal Javanese culture and are naturally ingrained in the characters of most Javanese (Koentjaraningrat, 2015). Thus, in facing a problem, children are expected to seek help toquickly and thoroughly resolve the problem. However, in some cases of bullying, children often have difficulty getting help from bystanders due to an imbalance of power compared to the perpetrators (Olweus, 1996). In addition, victims are usually children who have few friends or no friends who can support them in the face of bullying (Georgiou \& Stavrinides, 2008).

From the perspective of bystanders, retaliation is also a typical response given by victims of bullying. However, further research is needed to understand whether retaliation is a primary or alternative response. This suggestion is supported by Sokol et al. (2016), who stated that victims' response to bullying is a strategy to face or stop the bully. Victims of bullying can show differing responses during different bullying episodes. Thus, from the perspective of a bystander, the victim's response cannot be ascertained as a single response. Instead, it is very 
likely the result of the victim's evaluation after providing an initial response which was deemed ineffective in dealing with bullies. The victims' process of evaluation towards their response can also be seen as a characteristic of the Javanese people, known as the three 'nga' ('ngalah' or relent, 'ngalih' or leave, and 'ngamuk' or anger).

Furthermore, Abimanyu (2014) explained that in the face of a problem, Javanese people prioritize relentment or giving in ('ngalah') to maintain harmony and avoid conflict. If 'ngalah' does not stop the other party from continuing to act unpleasantly, victims will proceed to the second 'nga,' which is 'ngalih' (avoidance) in order to stop receiving adverse treatment. The last step is 'ngamuk' (using anger) if the victim continues to be treated negatively after giving in and avoiding. In the context of the victim's response, 'ngamuk' is a response to fight the bullies.

The data from this study also indicated no differences between the five sampled cities in terms of the victim's response. Bullying victimsfrom all five cities reported helplessness as the highest response, despite variations of Javanese culture and traits between them. Semarang, Pemalang, dan Tegal are coastal cities with a 'coastal' culture and is less influenced by the Javanese culture. For example, they do not use the Javanese language in everyday life as frequently as people from the other cities. Meanwhile, the city of Wonosobo is located in a mountainous area with prominent Javanese culture. Lastly, Yogyakarta is the centre of Javanese culture and teachings (Endraswara, 2012). Helplessness-related responses involve victims not doing anything to seek help. Helplessness is related to Javanese teachings 'narima ing pandum' which means being utterly resigned to all decisions determined by God (Endraswara, 20I5). Everything that happens in life under the will of God; When one's child becomes a victim of bullying, the fate must be accepted; hence, there is no need to fight back. This concept in the context victim's response to bullying needs to be further investigated to achieve a clear picture of the meaning of not doing anything when being bullied.

No significant difference between the responses of victims of grade 4, 5, and 6 was found. The majority of respondents from the three grades perceive victims' responses to bullying as a form of helplessness. This can be explained by the cultural theory of Koentjaraningrat 
(20I5), which stated a relationship between culture and social systems that encompasses the interaction between human activities based on customs of conduct. Thus the Javanese customs of behavior are relatively the same at every age level, although with different levels of understanding. This cultural approach is also in line with Bandura's social learning theory, which states that children learn behavior by looking at the behavior of others (Levine \& Munsch, 2014). Human behavior is a reciprocal relationship between person and environment. From the perspective of developmental psychology, Piaget (Slavin, 20II) explained that children from age 7 to II years are in the concrete operational stage, hence, displaying relatively similar behavior.

Respondents' expectation of how victims should respond to bullying is in line with their perception regarding victim's response to bullying, i.e., victims should report the act of bullying to people with authority such as teachers, parents, or police. As such, reporting acts of bullying is perceived as the right solution to stop bullying. Additionally, bystanders suggest that victims should retaliate when being bullied. This suggestion is interesting as retaliation is uncommon in the Javanese culture.Javanese people will only fight back or retaliate when a problem can not be resolved peacefully, such as by staying quiet or through avoidance (Endraswara, 2012). Another response suggested by subjects is to forgive the bully, although only $7.20 \%$ of all research subjects provided this answer. However it remains an interesting point of view to study as giving forgiveness is relatively hard for young children astheir concept of morality is still in its conventional stage (Kohlberg as cited in Levine \& Munsch, 2014). In the conventional stage, someone is considered wrong when he or she violates the rules and is considered right when adhering to it. Bullying is considered abehavior that violates the rules; hence, there is a need for punishment, not forgiveness. Thus subjects' suggestion for the victims of bullying to forgive perpetrators requires moral understanding that is higher than the conventional stage. In association with thejavanese culture, this subjects' attitude reflects the application of Javanese characteristics, which always attempts to maintain harmony and avoid disputes (Abimanyu, 2014).

\section{Conclusion}


This research found that the most common response of victims of bullying is helplessness, followed by counteraggression and nonchalance. There is no difference in the types of dominant response between cities with different demographical characteristics. The type of response that was most dominant in grade 4, 5, and 6 was helplessness. Respondents suggested that the most appropriate response is to report to the authority, fight back, seek help, be patient, and forgive the bully. This research needs further exploration of responses related to forgiving and patience in order to understand the true motive of Javanese students, who tend to use indirect communication and symbols.

\section{Reference}

Abimanyu, S. (20|4). Babad tanah Jawi. Jogjakarta: Laksana.

Alavi MD, N., Roberts MBBS, MRCPsych, FRCPC, MSc, N., Sutton BSc, C., Axas MSW, RSW, N., \& Repetti RN, L. (2015). Bullying victimization (being bullied) among adolescents referred for urgent psychiatric consultation: Prevalence and association with suicidality/victimisation par intimidation (se faire intimider) chez des adolescents adressés à une consultation psychia. Canadian Journal of Psychiatry, 60(10), 427-43I. https://doi.org/https://dx.doi.org/I0.II77/07067437/50600I003

Albdour, M., Lewin, L., Kavanaugh, K., Hong, J. S., \& Wilson, F. (2016). Arab American adolescents' perceived stress and bullying experiences: A qualitative study. Western Journal of Nursing Research, 1939459166782 I4. https://doi.org/I0.1 I77/01939459166782/4

Berkowitz, R. (2014). Student and teacher responses to violence in school: The divergent views of bullies, victims, and bully-victims. School Psychology International, 35(5), 485-503. https://doi.org/I0.1 I77/0143034313511012

Busch, V., Laninga-Wijnen, L., van Yperen, T. A., Schrijvers, A. J. P., \& De Leeuw, J. R. J. (20I5). Bidirectional longitudinal associations of perpetration and victimization of peer bullying with psychosocial problems in adolescents: A cross-lagged panel study. School Psychology International, 36(5), 532-549. https://doi.org/I0.1 I 77/0 I430343 I56040 I8

Carmey, A. G., \& Merrell, K. W. (200I). Bullying in schools: Perspectives on understanding and preventing an international problem. School Psychology International. Retrieved from http://journals.sagepub.com/home/spi

Cheng, Y.-Y., Chen, L.-M., Ho, H.-C., \& Cheng, C.-L. (20I I). Definitions of school bullying in Taiwan: A comparison of multiple perspectives. School Psychology International, 32(3), 
227-243. https://doi.org//0.I I77/0 |430343 I | 404I30

Cowie, H., \& Berdondini, L. (2016). The expression of emotion in response to bullying The expression of emotion in. 2752(February). https://doi.org// 0. I080/I36327502005070 I 8

Craig, W., Pepler, D., \& Blais, J. (2007). Responding to bullying: What works? School Psychology International, 28(4), 465-477. https://doi.org/I0. I I77/0 I43034307084I 36

Endraswara, S. (20I2). Falsafah hidup jawa, menggali mutiara kebijakan dari intisari filsafat Kejawen. Jakarta: Cakrawala.

Endraswara, S. (20I5). Etnologi Jawa: Penelitian, perbandingan dan pemaknaan budaya. Yogyakarta: CAPS (Center for Academic Publishing Service).

Georgiou, S. N., \& Stavrinides, P. (2008). Bullies, victims and bully-victims: Psychosocial profiles and attribution styles. School Psychology International, 29(5), 574-589. https://doi.org/10.1 I77/0143034308099202

Hana. (2013, December). Yogyakarta menduduki peringkat tertinggi kasus bullying. Radio Edukasi. Retrieved from http://radioedukasi.kemdikbud.go.id/read/869/

Hong, J. S., Kral, M. J., \& Sterzing, P. R. (20I5). Pathways from bullying perpetration, victimization, and bully victimization to suicidality among school-aged youth. Trauma, Violence, \& Abuse, I6(4), 379-390. https://doi.org/I0. I I77//5248380 I4537904

Idrus, M. (20I2). Pendidikan karakter pada keluarga Jawa. Jurnal Pendidikan Karakter, II(2), II8-130.

Kamarea, L. B. (2018). Kontrol diri dan agresivitas orang Jawa dan orang Papua. Universitas Muhammadiyah Malang.

Kochenderfer-ladd, B. (2004). Articles peer victimization : The role of emotions in adaptive and maladaptive Coping. Social Development, 13(3), 329-349.

Koentjaraningrat. (2015). Kebudayaan mentalitas dan pembangunan. Jakarta: PT Gramedia.

Kompas.com. (2008, May). Kekerasan di sekolah, Yogya paling tinggi.Kompas.com. Retrieved from https://nasional.kompas.com/read/2008/05/I7/I449I76I/

Levine, L. E., \& Munsch, J. (20I4). Child development, an active learning approach (2nd ed.). California: SAGE Publications Ltd.

Martin, E. (2015). School violence and victim-bully relationships: Examining environmental contextual issues that contribute to aggression. Northcentral University.

Nash, L. (20I2). New Jersey's Anti-bullying fix: A solution or the creation of an even Greater First Amendment Problem? Brigham Young University Law Review, 2012(3), 1039-1070. 
Retrieved from

http://search.ebscohost.com/login.aspx?direct=true\&db=lpb\&AN=83 I 76200\&site=ehost -live

Olweus, D. (1996). Bullying at school: knowledge base and an effective intervention program. Annals of the New York Academy of Sciences, Vol. 794, pp. 265-276. https://doi.org/I0.1 I I I/j.I749-6632.1996.tb32527.x

Rachim, R. L., \& Nashori, H. F. (2007). Nilai budaya Jawa dan perilaku nakal remaja Jawa. Indigenous, 9(I), 30-43.

Rigby, K. (2002). New perspectives on bullying. London: Jessica Kingsley Publishers Ltd.

Salmivalli, C., Karhunen, J., \& Lagerspetz, K. M. J. (1996). How Do the victims respond to bullying ?22, 99-109.

Sanders, Cheryl E and Phye, G. D. (2004). Bullying, implications for the classroom. San Diego: Elsevier Academic Press.

Santoso, B. (2012). The Influences of Javanese Culture in power of making decisions in indonesian universities: Case studies in MM programmes. Journal of Indonesian Economy and Business, 27(2), 224-24I.

Seal, D., \& Young, J. (2003). Bullying and victimization: Prevalence and relationship to gender level, ethnicity, self-esteem, and depression. Adolescence, 38(I52), 735.

Shin, Y. (2010). Psychosocial and friendship characteristics of bully/victim subgroups in Korean primary school children. School Psychology International, 3 I (4), 372-388. https://doi.org/I0.1 I77/0143034310377296

Sittichai, R., \& Smith, P. K. (20I5). Bullying in South-East Asian Countries: A review. Aggression and Violent Behavior, 23, 22-35. https://doi.org/I0.1016/j.avb.2015.06.002

Slavin, R. E. (20I I). Psikologi pendidikan, teori dan praktik (9th ed.). Jakarta: Indeks.

Smith, P. K., Cowie, H., Olafsson, R. R., \& Liefooghe, A. P. (2002). Definitions of bullying: A comparison of terms used, and age and gender differences, in a Fourteen-Country international comparison. Child Development, 73(4), III9-1 I33. https://doi.org/I0.1 I I I/ /467-8624.0046 I

Smith, P. K., Pepler, D., \& Rigby, K. (Eds.). (2004). Bullying in school: How successful can interventions be? Retrieved from http://www.cambridge.org

Sokol, N., Bussey, K., \& Rapee, R. M. (2016). Victims' responses to bullying: The gap between students ' evaluations and reported responses. School Mental Health. https://doi.org/10.1007/s I2310-016-9185-0 
Solberg, M. E., \& Olweus, D. (2003). Prevalence estimation of school bullying with the olweus bully/victim questionnaire. Aggressive Behavior, 29(3), 239-268. https://doi.org//0.1002/ab.10047

Trach, J., Hymel, S., Waterhouse, T., \& Neale, K. (2010). Bystander responses to school bullying: A cross-sectional investigation of grade and sex differences. Canadian Journal of School Psychology, I, I |4-I30. https://doi.org/I0.I I 77/0829573509357553

Wolke, D., Woods, S., Stanford, K., \& Schulz, H. (200I). Bullying and victimization of primary school children in England and Germany: Prevalence and school factors. British Journal of Psychology, 92(4), 673-696. https://doi.org/10.1348/0007I260I I624I9 